Gut, 1960, 1, 125.

\title{
SERUM AMYLASE AND SERUM LIPASE LEVELS IN MAN AFTER ADMINISTRATION OF SECRETIN AND PANCREOZYMIN
}

\author{
BY \\ P. BURTON, ELIZABETH M. HAMMOND, A. A. HARPER, HENRY T. HOWAT, \\ J. E. SCOTT, and H. VARLEY

\begin{abstract}
From a Medical Unit and the Clinical Laboratory, Manchester Royal Infirmary, and the Department of Physiology, Medical School, King's College, Newcastle upon Tyne
\end{abstract}

A simple evocative test has been used to study pancreatic function. Serial estimations of amylase and lipase in blood serum are made at intervals up to six hours and again at 24 hours after injecting intravenously standard doses of secretin and pancreozymin. The results of 213 tests on a normal group, in pancreatic disease, in biliary and hepatic diseases have been analysed and compared with the results of duodenal intubation and an oral glucose tolerance test. A combined evocative test and oral glucose tolerance test provide evidence of pancreatic dysfunction in the majority of cases of cancer of the pancreas and chronic pancreatitis. The conditions of the test are described and the pathological lesions in which false positive evocative tests may be found are indicated.

The simple evocative test provides the earliest biochemical evidence of pancreatic disease in some patients with cancer of the pancreas and chronic pancreatitis.

Though part of the amylase found in the blood stream of man in health may derive from the liver and salivary glands, most of it originates in the pancreas. There is little lipase of pancreatic origin in the blood of normal man, though serum contains esterases which are capable of acting on esters of fatty acids of low molecular weight. In pancreatic disease, however, pancreatic duct obstruction may lead to the passage of amylase and lipase from the acini and ductules of the pancreas into the portal blood stream and increased amounts of enzymes are found in systemic venous blood. In clinical practice estimation of serum amylase and lipase has proved of great value in diagnosing an acute attack of pancreatitis, although in chronic pancreatitis and cancer of the pancreas even repeated estimations of the enzymes are less helpful. This can be attributed to a more gradual obstruction of the duct and a diminution pari passu in functional activity of the gland in these diseases.

Many workers have tried to modify the conditions in which serum enzymes are measured in order to increase the sensitivity of the tests in chronic and relapsing pancreatitis and in cancer of the pancreas. This has been done in three ways; by stimulating the gland to secrete in response to secretin and parasympathomimetic drugs, by giving morphine to induce spasm of the sphincter of Oddi and thus increase pressure in the ducts, or by combining these methods.

Popper and Necheles (1943) showed experimentally in dogs that if the pancreas was powerfully stimulated by a combination of secretin and mecholyl the serum lipase rose in animals with a normal pancreas but not in those in which the pancreas had atrophied. By contrast a less vigorous stimulus, secretin alone, produced no elevation in normal dogs, but a rise was found after the pancreatic duct was tied (Popper, Olson, and Necheles, 1943). Since then evocative serum enzyme studies have developed clinically along the two main lines which correspond with these experimental findings. It is necessary to draw a clear distinction between the two which are frequently confused. The first type of test is designed, by intense stimulation (frequently combined with morphine), to produce in subjects with a normal pancreas a rise in serum enzyme levels, which would be less marked or absent in chronic destructive lesions of the gland. In the second type a milder stimulus is applied which would not raise the serum enzyme levels appreciably if the outflow from the healthy gland was unobstructed, but might be expected to do so if the glandular secretion were dammed up behind an 
inflammatory or malignant obstruction of the duct.

As an example of the first variety, which might be called a combined obstructive-evocative test, Myhre, Nesbitt, and Hurly (1949) made serial determinations of serum enzymes after vigorous stimulation of the pancreas with secretin and the parasympathomimetic drug mecholyl, with the addition of morphine. They obtained no elevation of serum amylase and lipase in patients with advanced pancreatic disease. However, a significant rise of serum enzymes was found in only $70 \%$ of normal subjects, a proportion not sufficiently high to justify the use of their secretin-mecholyl and secretin-morphine tests in clinical practice. For this reason the method has been largely discarded.

The alternative method, a simple evocative test in which a milder stimulus is given, proved more promising. Prostigmin methyl sulphate intramuscularly (Knight, Muether, and Sommer, 1949) and secretin intravenously (Lopusniak and Bockus, 1950) were given to normal subjects and patients with pancreatic disease. In the normal group no elevation of serum enzymes was observed, but in some cases of pancreatitis and cancer of the pancreas a rise occurred. Lopusniak and Bockus found that this rise was more likely to occur when the initial enzyme values were high but was less often seen in patients with normal resting values. Dreiling and Richman (1954) reviewed the literature and concluded that evocative serum enzyme studies of this type after intravenous secretin were less useful than other methods of evaluating pancreatic function, such as the study of secretin-stimulated pancreatic secretion. In their own experiments, however, Dreiling and Richman did not estimate serum lipase but relied solely on serum amylase values.

While carrying out a study of the effect of secretin and pancreozymin on the amount and composition of duodenal contents (Burton, Evans, Harper, Howat, Scott, Oleesky and Varley, 1960), we have also made serial observations on the levels of serum amylase and lipase before and after stimulating the pancreas. An analysis of the results has been made and correlated with the state of pancreatic function determined by examining duodenal contents and by performing a standard oral glucose tolerance test.

\section{METHODS}

Secretin and pancreozymin were prepared from pig intestine and assayed according to the method of Crick, Harper, and Raper (1949). Tests of toxicity and for anaphylaxis were carried out. Details of the preparation and administration of the extracts are given elsewhere (Burton et al., 1960). In most instances the dose of both secretin and pancreozymin has been 1.7 units per kilogram of body weight.
The patient fasts overnight. A control sample of about $10 \mathrm{ml}$. of venous blood is collected, after which secretin is given intravenously. Twenty-five minutes later a postsecretin sample is removed, after which the appropriate dose of pancreozymin is injected. Thirty minutes later a post-pancreozymin sample is collected. Further blood samples are taken, two, four, and six hours after secretin. Food is permitted after the two-hour sample, and in most cases a postprandial sample has been collected 24 hours later.

Serum amylase is estimated by a modification of the saccharogenic method of Somogyi (1938), reducing substance being measured by Maclean's method and serum lipase by a modification of the method of Cherry and Crandall (1932) in which triolein is the substrate. Attempts made in our laboratory to estimate changes of esterase in the serum of patients with pancreatic disease, using tributyrin as substrate, according to the method of Goldstein and Roe (1943) and Goldstein, Epstein, and Roe (1948), have proved unsuccessful. Henry, Sobel, and Berkman (1957) report a similar failure in acute pancreatitis in man. The Somogyi and Cherry and Crandall techniques have given results which are easily reproduced with accuracy. In duplicate analyses of amylase on 27 specimens of serum, in which the values ranged from 19 to 332 units per $100 \mathrm{ml}$., the range of the differences between duplicate analyses was 0 to 28 units per $100 \mathrm{ml}$., and the mean of these differences was 6.5 units per $100 \mathrm{ml}$. Duplicate analyses of lipase were made on 65 samples of serum and duodenal contents, with values ranging between 0.1 and 5.9 units per $\mathrm{ml}$. The range of the differences between duplicates was 0 to 0.8 units per ml., and the mean of these differences was 0.18 units per $\mathrm{ml}$.

An oral glucose tolerance test of $50 \mathrm{~g}$. of glucose has been given. Adequate carbohydrate intake has, as far as possible, been assured before the test has been accepted as valid. As it is convenient to express the results of the oral glucose tolerance test by a single figure, it has been assumed in this paper that glucose tolerance is impaired when the blood level of reducing substances exceeds $140 \mathrm{mg}$. per $100 \mathrm{ml}$. of capillary blood two-and-a-half hours after the oral dose of $50 \mathrm{~g}$. of glucose has been given to a fasting patient and normal when the two-and-a-half hour value is less than this figure.

In many instances the duodenal juice has been quantitatively aspirated in the first hour after stimulation with secretin, and the volume, bicarbonate, and output of amylase, trypsin, and lipase obtained in response to pancreozymin have been compared with the response to secretin (loc. cit.).

\section{RESULtS}

NoRmal SUbJECTs.- In a group of 51 normal individuals the mean fasting serum amylase was 70 units $/ 100 \mathrm{ml}$. of serum (S.E. of mean $\pm 3 \cdot 6$ ). The upper limit of normal at the $99 \%$ limit of confidence (mean $+2 \cdot 58 \sigma$ ) was 134 units. In 42 fasting normal persons the mean serum lipase was $0.51 \pm 0.04$ units $/ \mathrm{ml}$. of serum, the upper limit of 

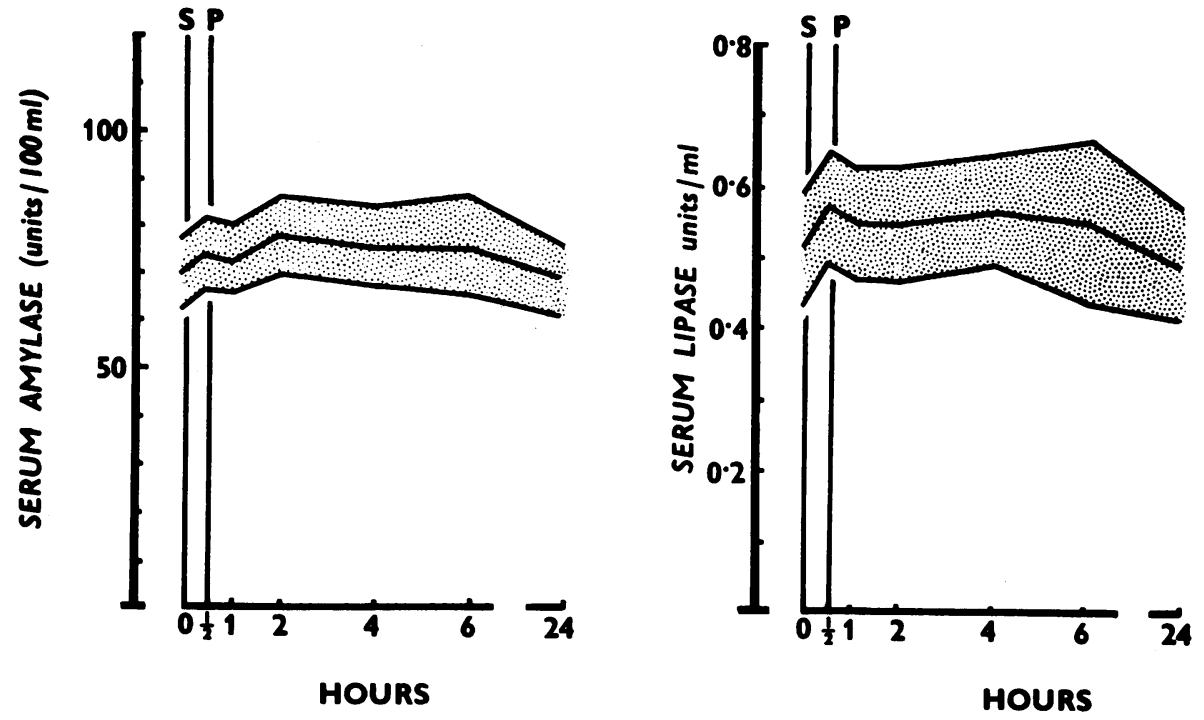

FIG. 1.-The Evocative Test.-The pattern of the mean serum amylase in 51 normal subjects and the mean serum lipase in 42 normal subjects \pm 2 S.E. of means, obtained in response to secretin $(S)$ and pancreozymin $(P)$.

normal at the $99 \%$ limit of confidence being $1 \cdot 15$ units.

Serial enzyme estimations after secretin and pancreozymin were made in a normal group comprising 51 individuals, made up of (a) 26 healthy men and women aged 20 to 45 years in whom the pancreas was assumed to be normal, (b) 14 adult patients varying in age from 20 to 63 suffering from various diseases not affecting the liver, gall bladder, pancreas, or kidneys, and (c) 11 adult patients aged 45 to 75 suffering from malignant disease not involving the extrahepatic bile ducts or pancreas.

For the individual in health both serum amylase and serum lipase are relatively constant over a period of time. The mean of the differences between the fasting control sample and the postprandial sample taken 24 hours later in the normal group was for amylase 12.5 units (43 subjects) and for lipase 0.12 units (38 subjects).

The pattern of the mean response of serum amylase and lipase to secretin and pancreozymin in the normal group is shown in Fig. 1. There is no significant difference in either serum amylase or lipase between any of the three subgroups which have been combined to form the normal group for serum enzymes. In the 51 subjects of this normal group in whom serum amylase was measured there is no significant alteration in the enzyme levels in the first three samples. The slightly higher means for the fourth and fifth samples are derived from a smaller number of observations ( 44 and 41 re- spectively) than those for the first three samples. By chance the cases unrepresented in the fourth and fifth means had rather low serum enzyme levels which explains the fortuitous increase in these means. No significant pattern can be discerned in the mean values in the $\mathbf{4 2}$ subjects in whom serum lipase was recorded. It seems reasonable to derive from the highest enzyme value reached in each subject a measure of the upper limit of serum amylase and lipase in normal subjects after secretin and pancreozymin (Fig. 2). In the normal group the mean maximal concentration of amylase was $83 \pm 4$ units $/ 100 \mathrm{ml}$. and of lipase $0.7 \pm 0.05$ units $/ \mathrm{ml}$. At the $99 \%$ limit of confidence the normal maximal amylase was 158 units $/ 100 \mathrm{ml}$. of serum and the maximal lipase 1.5 units $/ \mathrm{ml}$. of serum. In 21 of the 40 cases of the first two subgroups of the normal group the duodenal contents have been recovered. This modification of the test was not found to alter the pattern or values of the responses. In the normal group the postprandial values for both serum amylase and lipase taken 24 hours later all fell within the normal range of values.

Pancreatic Disease.-Results are expressed in terms of (1) cancer of the pancreas and (2) pancreatitis.

(1) Cancer of the Pancreas.-Primary cancer of pancreas was studied in 36 patients, the location of all but one being verified at operation or at necropsy. Three of these were studied following subtotal 


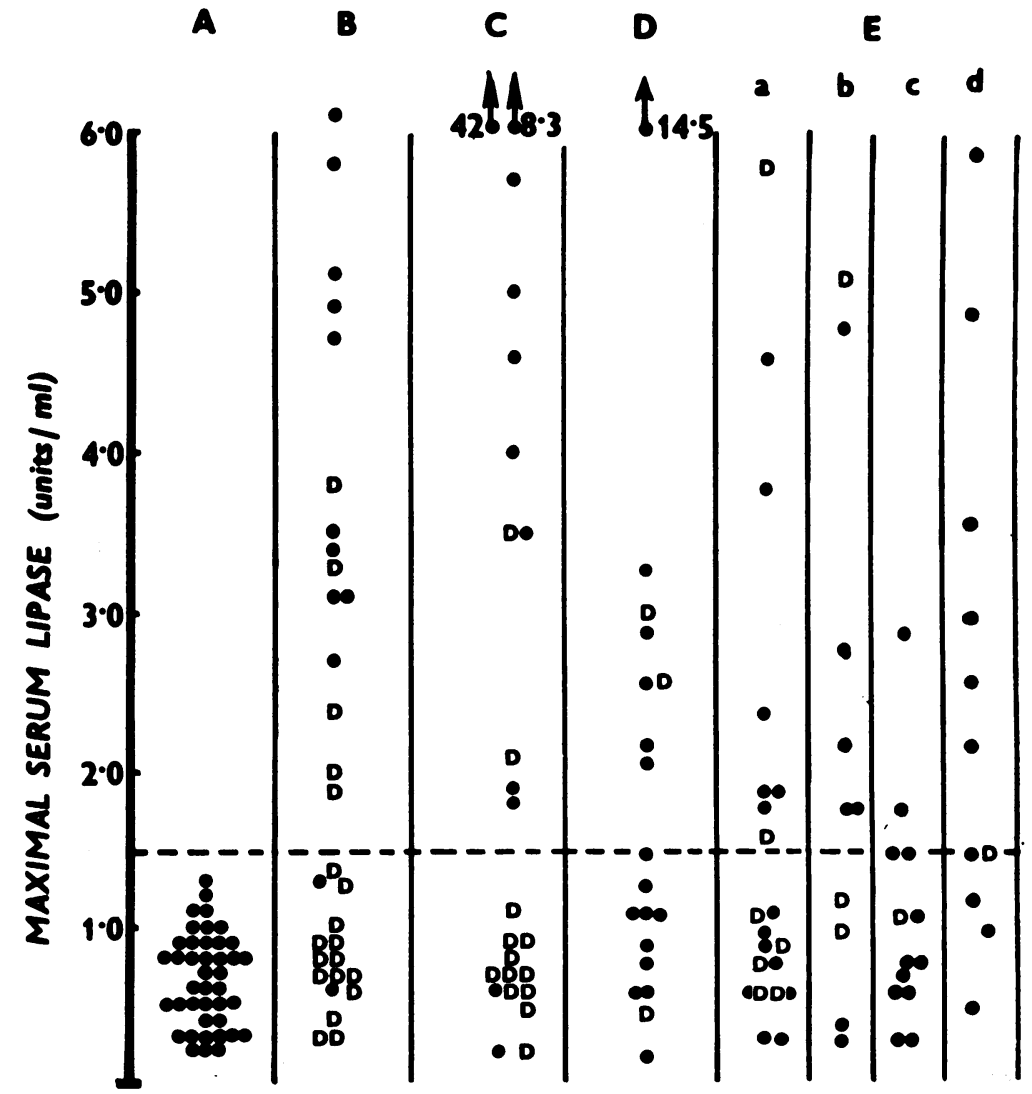

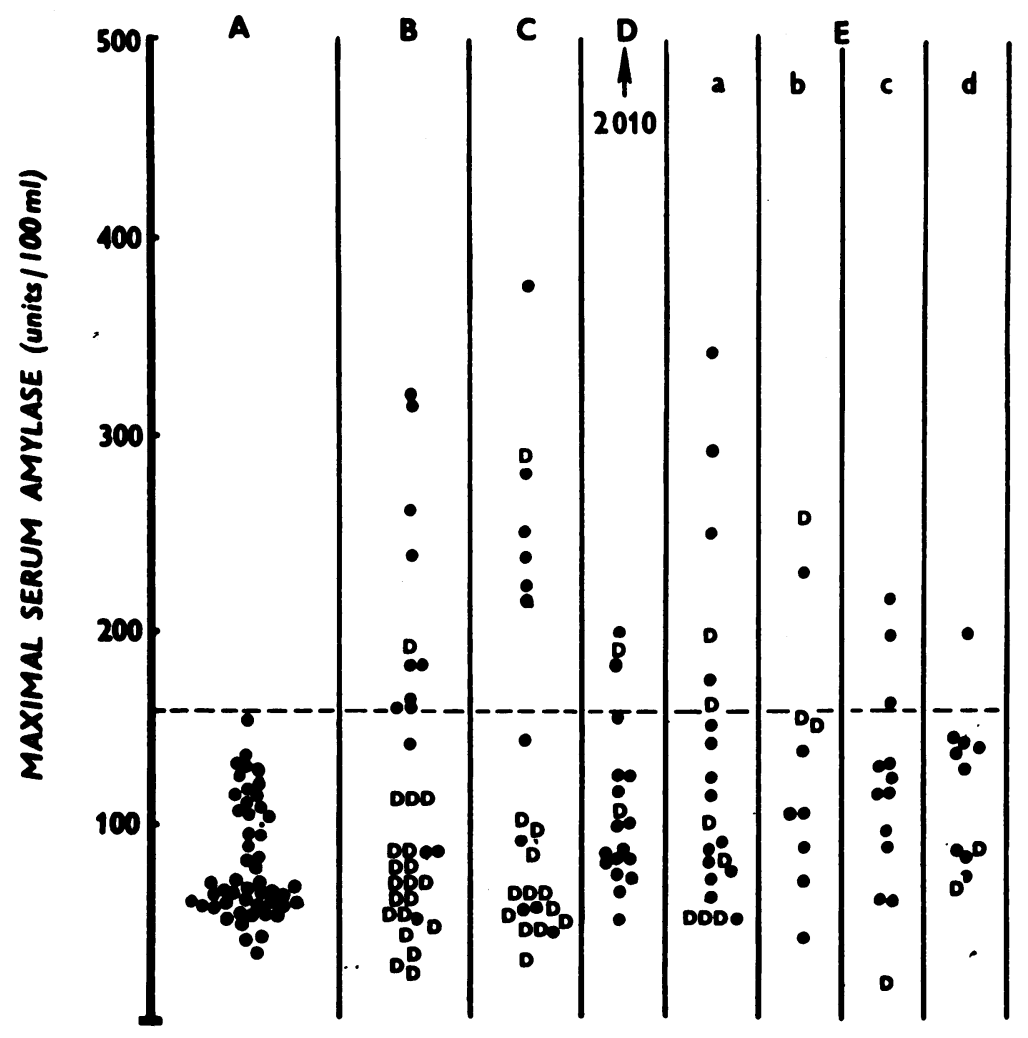

Fig. 2.-The Evocative Test.-The

distribution of the maximal serum amylase and lipase evoked by secretin and pancreozymin in normal and abnormal subjects (•- nondiabetic; $D$,-diabetic). The upper limits of normal (for amylase 158 units $100 \mathrm{ml}$. and for lipase 1.5 units $/ \mathrm{ml}$.) are indicated by interrupted lines.

A. Normal group

B. Cancer of pancreas

C. Chronic pancreatitis

D. "Post-acute pancreatitis"

E. Biliary disease

(a) of gall bladder

(b) of common bile duct

(c) post cholecystectomy

(d) cancer of the biliary tract

426
ט

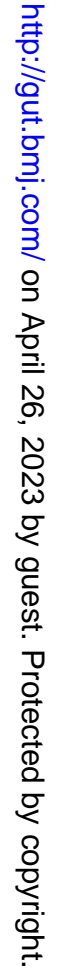


pancreatectomy. Of the remaining 33,16 originated in the head of the pancreas, 10 in the body, three occupied both regions diffusely, and four were ampullary cancers. At operation carried out at about the time of the test secondary deposits were obvious in the liver in nine of the group. In two cases of primary cancer of the stomach the pancreas was secondarily involved.

Early in the study it was appreciated that a positive evocative response was less likely to be obtained in patients in whom hyperglycaemia and glycosuria had been found. Thereafter an oral glucose tolerance test was performed as near to the time of the evocative test as practicable and on the results 31 cases have been divided into 11 in whom the glucose tolerance test was negative (non-diabetic) and 20 in whom it was positive (diabetic). Collections of duodenal contents were made simultaneously with the evocative tests in 17 cases, and on these results two further subgroups have been distinguished. In 10 patients the volume of duodenal contents was significantly reduced (less than $150 \mathrm{ml}$. in 60 minutes). In seven of these the glucose tolerance was also impaired; in two it was normal, and in the tenth it could not be determined. In the seven patients with normal duodenal output, two had moderately and two slightly impaired glucose tolerance. The glucose tolerance was normal in the other three.

The mean responses of the 33 patients suffering from primary cancer of the pancreas and of the subgroups based on the results of the glucose
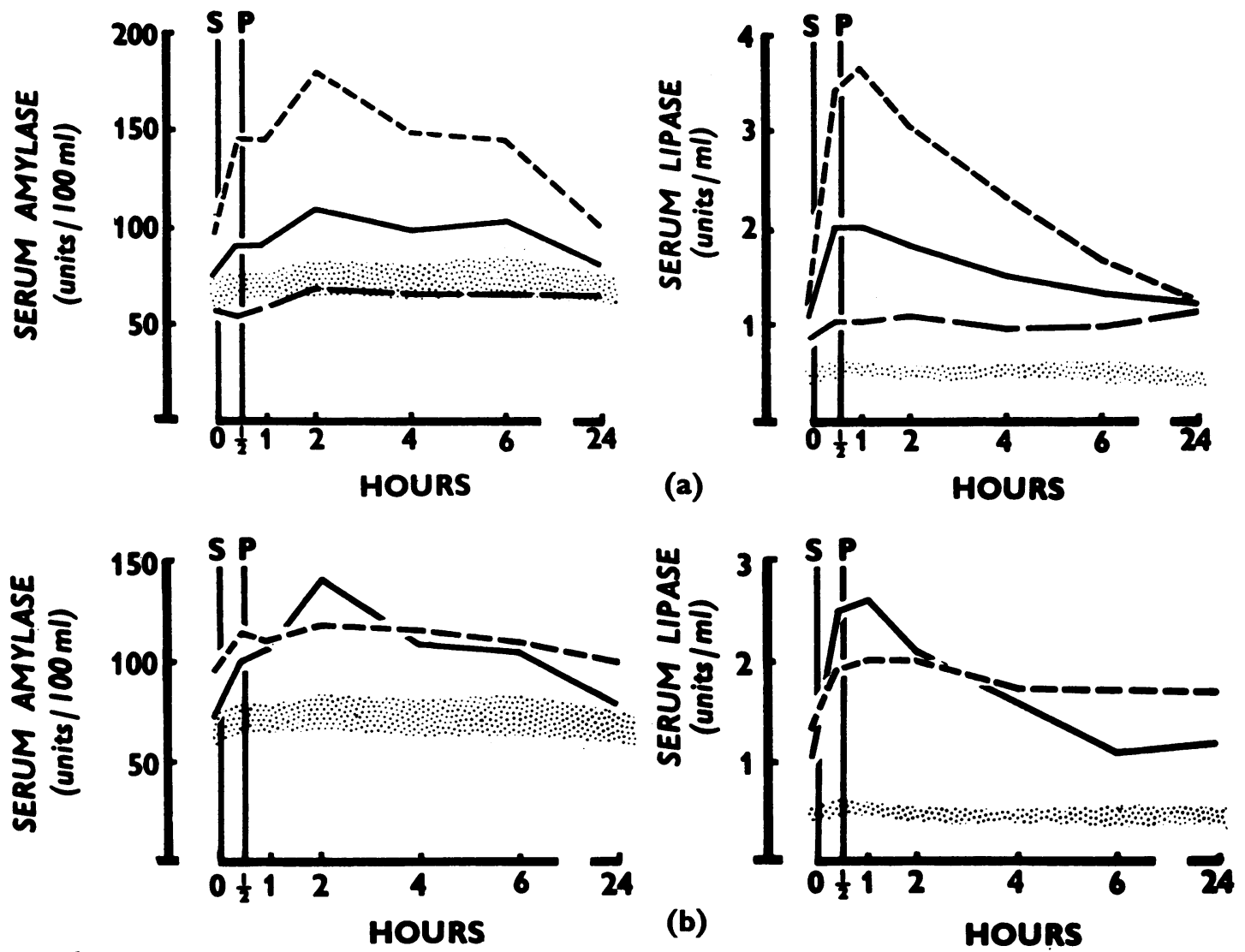

FIG. 3.-The Evocative Test.-Mean serum amylase and lipase evoked by secretin $(S)$ and pancreozymin $(P)$ in cancer of the pancreas. The limits of normal ( \pm 2 S.E. of the normal means) are indicated by the stippled areas, while the figures in brackets indicate the number in each subgroup. The same symbols and conventions are used in Figs. 4 and 5. (a) Whole group with diabetic and non-diabetic subgroups.

Whole group (33) - - - - - - - Non-diabetic (11) Diabetic (20)

(b) Subgroups with normal and reduced volume of duodenal contents. Normal volume (7) 
TABLE I

\begin{tabular}{|c|c|c|c|c|c|c|c|c|c|c|c|c|c|c|}
\hline \multirow{3}{*}{ Group } & \multirow{3}{*}{$\begin{array}{l}\text { No. of } \\
\text { Cases }\end{array}$} & \multirow{2}{*}{\multicolumn{7}{|c|}{ Samples }} & \multicolumn{6}{|c|}{ Significance of Difference between Means } \\
\hline & & & & & & & & & \multicolumn{3}{|c|}{$\begin{array}{l}\text { Control Samples of Normal } \\
\text { and Abnormal Groups }\end{array}$} & \multicolumn{3}{|c|}{$\begin{array}{l}\text { Sample in Abnormal Group } \\
\text { Showing Maximum Increase } \\
\text { (or Reduction) and Correspond- } \\
\text { ing Normal Sample }\end{array}$} \\
\hline & & $\begin{array}{c}\text { Con- } \\
\text { trol }\end{array}$ & Post- & $\begin{array}{l}\text { Post- } \\
\text { PZN }\end{array}$ & $2 \mathrm{Hr}$. & $4 \mathrm{Hr}$. & $6 \mathrm{Hr}$. & $24 \mathrm{Hr}$. & tor $c$ & $\mathbf{P}$ & $\begin{array}{c}\text { Sig- } \\
\text { nificance }\end{array}$ & tor c & $\mathbf{P}$ & $\begin{array}{c}\text { Sig- } \\
\text { nificance }\end{array}$ \\
\hline \multirow[b]{2}{*}{$\begin{array}{l}\text { Normal } \\
\text { Standard error }\end{array}$} & \multicolumn{13}{|c|}{ AMYLASE } & \\
\hline & 51 & $\begin{array}{c}70 \\
3 \cdot 6\end{array}$ & $\begin{array}{l}74 \\
3 \cdot 8\end{array}$ & $\begin{array}{l}73 \\
3.9\end{array}$ & $\begin{array}{l}78 \\
4 \cdot 1\end{array}$ & $\begin{array}{l}76 \\
4 \cdot 3\end{array}$ & $\begin{array}{l}76 \\
5 \cdot 4\end{array}$ & $\begin{array}{l}69 \\
3 \cdot 7\end{array}$ & & & & & & \\
\hline $\begin{array}{l}\text { Carcinoma of pancreas } \\
\text { Total } \\
\text { GTT - ve } \\
\text { GTT + ve } \\
\text { Normal duodenal vol. } \\
\text { Reduced duodenal vol. }\end{array}$ & $\begin{array}{r}33 \\
11 \\
20 \\
7 \\
10\end{array}$ & $\begin{array}{l}75 \\
98 \\
56 \\
72 \\
92\end{array}$ & $\begin{array}{r}90 \\
145 \\
53 \\
99 \\
113\end{array}$ & $\begin{array}{r}92 \\
145 \\
57 \\
105 \\
108\end{array}$ & \begin{tabular}{|r|}
108 \\
180 \\
68 \\
141 \\
118
\end{tabular} & $\begin{array}{r}97 \\
149 \\
66 \\
108 \\
114\end{array}$ & $\begin{array}{r}102 \\
145 \\
65 \\
103 \\
108\end{array}$ & $\begin{array}{r}81 \\
100 \\
66 \\
78 \\
100\end{array}$ & $\begin{array}{l}2.54 \\
1.68 \\
1.60\end{array}$ & $\begin{array}{l}<0.02>0.01 \\
<0.1>0.05 \\
<0.2>0.1\end{array}$ & $\begin{array}{r}\text { NT } \\
+ \\
0 \\
\text { NT } \\
0\end{array}$ & $\begin{array}{l}2 \cdot 08 \\
6 \cdot 80 \\
2 \cdot 68 \\
4 \cdot 00 \\
2 \cdot 16\end{array}$ & $\begin{array}{l}<0.04>0.03 \\
<0.001 \\
<0.01>0.001 \\
<0.001 \\
<0.05>0.02\end{array}$ & $\begin{array}{l}+\vec{N} \\
+++\overrightarrow{0} \\
+++0 \\
+++\frac{0}{5}\end{array}$ \\
\hline $\begin{array}{l}\text { Chronic pancreatitis } \\
\text { Total - ve } \\
\text { GTT - ve } \\
\text { GTT + ve } \\
\text { Normal duodenal vol. } \\
\text { Reduced duodenal vol. }\end{array}$ & $\begin{array}{r}23 \\
10 \\
13 \\
7 \\
7\end{array}$ & $\begin{array}{l}78 \\
93 \\
66 \\
73 \\
65\end{array}$ & $\begin{array}{r}94 \\
125 \\
71 \\
87 \\
59\end{array}$ & $\begin{array}{r}102 \\
144 \\
70 \\
95 \\
61\end{array}$ & $\begin{array}{r}106 \\
157 \\
71 \\
116 \\
57\end{array}$ & $\begin{array}{r}97 \\
130 \\
72 \\
87 \\
61\end{array}$ & $\begin{array}{r}95 \\
134 \\
62 \\
94 \\
62\end{array}$ & $\begin{array}{r}87 \\
110 \\
68 \\
81 \\
64\end{array}$ & $2 \cdot 35$ & $<0.05>0.02$ & $\begin{array}{l}\text { NT } \\
+ \\
\text { NT } \\
\text { NT } \\
\text { NT }\end{array}$ & $\begin{array}{l}1 \cdot 59 \\
5 \cdot 23 \\
2 \cdot 24 \\
1.94\end{array}$ & $\begin{array}{l}<0.2>0.1 \\
<0.001 \\
<0.05>0.02 \\
<0.1>0.05\end{array}$ & $\begin{array}{c}0 \\
++\frac{\check{D}}{+} \\
\mathrm{NT} \\
+\frac{1}{6} \\
0\end{array}$ \\
\hline Acute pancreatitis & 19 & 87 & 98 & 99 & 105 & 105 & 105 & 99 & $1 \cdot 44$ & $<0.2>0.1$ & $\mathbf{0}$ & 3.01 & $<0.01>0.001$ & ++ \\
\hline $\begin{array}{l}\text { Biliary tract and liver disease } \\
\text { Non-malignant group } \\
\text { A. Gall-bladder disease } \\
\text { B. Duct lesions } \\
\text { C. Cholecystectomy }\end{array}$ & $\begin{array}{l}22 \\
10 \\
13\end{array}$ & $\begin{array}{l}89 \\
78 \\
78\end{array}$ & $\begin{array}{r}109 \\
105 \\
96\end{array}$ & $\begin{array}{l}111 \\
118 \\
102\end{array}$ & $\begin{array}{l}110 \\
124 \\
106\end{array}$ & $\begin{array}{r}97 \\
135 \\
107\end{array}$ & $\begin{array}{r}97 \\
142 \\
101\end{array}$ & $\begin{array}{l}81 \\
86 \\
93\end{array}$ & $1 \cdot 58$ & $<0 \cdot 2>0 \cdot 1$ & $\begin{array}{l}\text { NT } \\
\text { NT }\end{array}$ & $\begin{array}{l}2.49 \\
3.82 \\
2.64\end{array}$ & $\begin{array}{l}<0.02>0.01 \\
<0.001 \\
<0.02>0.01 \\
<0.05>0.02\end{array}$ & 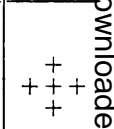 \\
\hline Carcinoma of biliary tract & 11 & 66 & 90 & 89 & 100 & 83 & 92 & 70 & & & NT & $2 \cdot 27$ & $<0 \cdot 2>0 \cdot 1$ & + \\
\hline \multirow[t]{2}{*}{ Liver group } & 13 & 74 & 90 & 102 & 93 & 92 & 93 & 88 & & & NT & 1.51 & & 0 \\
\hline & \multicolumn{14}{|c|}{ LIPASE } \\
\hline $\begin{array}{l}\text { Normal } \\
\text { Standard error }\end{array}$ & 42 & $\begin{array}{l}0.5 \\
0.04\end{array}$ & $\begin{array}{l}0.6 \\
0.04\end{array}$ & $\begin{array}{l}0.55 \\
0.04\end{array}$ & $\begin{array}{l}0.55 \\
0.04\end{array}$ & $\begin{array}{l}0.6 \\
0.04\end{array}$ & $\begin{array}{l}0.55 \\
0.06\end{array}$ & $\begin{array}{l}0.5 \\
0.04\end{array}$ & & & & & & \\
\hline $\begin{array}{l}\text { Carcinoma of pancreas } \\
\text { Total } \\
\text { GTT - ve } \\
\text { GTT + ve } \\
\text { Normal duodenal vol. } \\
\text { Reduced duodenal vol. }\end{array}$ & $\begin{array}{r}31 \\
11 \\
19 \\
7 \\
9\end{array}$ & $\begin{array}{l}1 \cdot 1 \\
1 \cdot 2 \\
0.9 \\
1 \cdot 0 \\
1 \cdot 3\end{array}$ & $\begin{array}{l}2.0 \\
3.4 \\
1.0 \\
2.5 \\
1.9\end{array}$ & \begin{tabular}{|l|}
$2 \cdot 0$ \\
$3 \cdot 65$ \\
$1 \cdot 0$ \\
$2 \cdot 6$ \\
$2 \cdot 0$
\end{tabular} & $\begin{array}{l}1 \cdot 8 \\
3 \cdot 1 \\
1 \cdot 1 \\
2 \cdot 1 \\
2 \cdot 0\end{array}$ & $\begin{array}{l}1.5 \\
2.3 \\
1.0 \\
1.6 \\
1.7\end{array}$ & $\begin{array}{l}1.3 \\
1.6 \\
1.0 \\
1.1 \\
1.7\end{array}$ & $\begin{array}{l}1.2 \\
1.2 \\
1.1 \\
1.2 \\
1 \cdot 7\end{array}$ & $\begin{array}{l}3 \cdot 43 \\
4 \cdot 66 \\
2 \cdot 73 \\
3 \cdot 52 \\
4 \cdot 35\end{array}$ & $\begin{array}{l}<0.001 \\
<0.001 \\
<0.01>0.001 \\
\bumpeq 0.001 \\
<0.001\end{array}$ & $\begin{array}{l}+++ \\
+++ \\
++ \\
+++ \\
+++\end{array}$ & $\begin{array}{r}4 \cdot 37 \\
11 \cdot 80 \\
3 \cdot 40 \\
7 \cdot 41 \\
4 \cdot 61\end{array}$ & $\begin{array}{l}<0.0001 \\
<0.001 \\
<0.01>0.001 \\
<0.001 \\
<0.001\end{array}$ & $\begin{array}{l}+++8 \\
+++3 \\
+++3 \\
+++0 \\
+++3\end{array}$ \\
\hline $\begin{array}{l}\text { Chronic pancreatitis } \\
\text { Total - v } \\
\text { GTT - ve } \\
\text { GTT + ve } \\
\text { Normal duodenal vol. } \\
\text { Reduced duodenal vol. }\end{array}$ & $\begin{array}{r}23 \\
10 \\
13 \\
7 \\
7\end{array}$ & \begin{tabular}{|l|l|}
0.8 \\
1.1 \\
0.6 \\
0.8 \\
0.5
\end{tabular} & $\begin{array}{l}1 \cdot 7 \\
2.95 \\
0.8 \\
2 \cdot 0 \\
0.4 \\
\end{array}$ & $\begin{array}{l}2.0 \\
3.7 \\
0.8 \\
2.3 \\
0.4\end{array}$ & \begin{tabular}{|l|l|}
1.7 \\
2.9 \\
0.85 \\
1.8 \\
0.5 \\
\end{tabular} & $\begin{array}{l}1.5 \\
2.4 \\
0.8 \\
1.6 \\
0.5\end{array}$ & $\begin{array}{l}1 \cdot 1 \\
1 \cdot 6 \\
0.7 \\
1 \cdot 05 \\
0 \cdot 4\end{array}$ & $\begin{array}{l}1.1 \\
1.6 \\
0.6 \\
1.0 \\
0.5\end{array}$ & $\begin{array}{l}1 \cdot 80 \\
3 \cdot 86 \\
2 \cdot 34\end{array}$ & $\begin{array}{l}<0.1>0.05 \\
<0.001 \\
<0.05>0.02\end{array}$ & $\begin{array}{c}0 \\
+ \\
\mathrm{NT} \\
+ \\
\mathrm{NT}\end{array}$ & $\begin{array}{l}2 \cdot 41 \\
7 \cdot 83 \\
1 \cdot 73 \\
5 \cdot 10\end{array}$ & $\begin{array}{l}<0.02>0.01 \\
<0.001 \\
<0.1>0.05 \\
<0.001\end{array}$ & 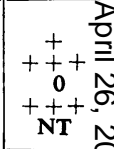 \\
\hline Acute pancreatitis & 18 & 1.0 & $1 \cdot 25$ & $1 \cdot 2$ & $1 \cdot 3$ & $1 \cdot 3$ & $1 \cdot 15$ & $1 \cdot 0$ & 3.79 & $<0.001$ & +++ & $5 \cdot 46$ & $<0.001$ & $+++N$ \\
\hline $\begin{array}{l}\text { Biliary tract and liver disease } \\
\text { Non-malignant group } \\
\text { A. Gall-bladder disease } \\
\text { B. Duct lesions } \\
\text { C. Cholecystectomy }\end{array}$ & $\begin{array}{l}21 \\
10 \\
13\end{array}$ & $\begin{array}{l}0.7 \\
1.0 \\
0.55\end{array}$ & \begin{tabular}{|l|}
$1 \cdot 3$ \\
$\mathbf{2} \cdot \mathbf{1}$ \\
1.0
\end{tabular} & $\begin{array}{l}1.2 \\
1.9 \\
1.0\end{array}$ & $\begin{array}{l}1.3 \\
1.6 \\
0.9\end{array}$ & $\begin{array}{l}1.2 \\
1.4 \\
0.7\end{array}$ & $\begin{array}{l}0.7 \\
1.3 \\
0.9\end{array}$ & $\begin{array}{l}0.5 \\
0.9 \\
0.6\end{array}$ & $\begin{array}{l}1 \cdot 30 \\
3 \cdot 175\end{array}$ & $\begin{array}{l}<0.2>0.1 \\
<0.01>0.001\end{array}$ & $\begin{array}{l}0 \\
++ \\
\text { NT }\end{array}$ & $\begin{array}{l}2 \cdot 39 \\
5.67 \\
3.655\end{array}$ & $\begin{array}{l}<0.02>0.01 \\
<0.001 \\
<0.001\end{array}$ & 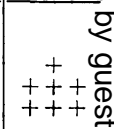 \\
\hline Carcinoma of biliary tract & 11 & 0.6 & $2 \cdot 4$ & $2 \cdot 1$ & $1 \cdot 8$ & $1 \cdot 4$ & $1 \cdot 15$ & 0.7 & & & NT & $6 \cdot 72$ & $<0.001$ & $+++\tau$ \\
\hline Liver group & 11 & $0 \cdot 7$ & $1 \cdot 4$ & $1 \cdot 35$ & $1 \cdot 2$ & 1.0 & 1.0 & 0.9 & $2 \cdot 175$ & $<0.05>0.02$ & + & $4 \cdot 14$ & $<0.001$ & +++ \\
\hline
\end{tabular}

Groups. $\quad$ GTT - ve and GTT + ve; patients in whom glucose tolerance was respectively normal or impaired.

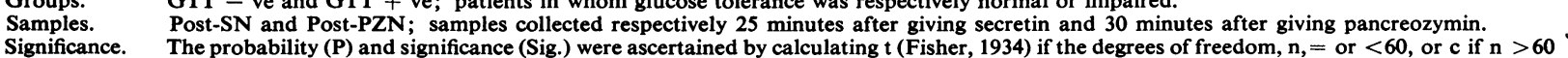

(Geigy, 1956). Means tested are in bold type.

NT Significance not tested if mean $< \pm 3$ S.E. from normal mean.

$0 \quad \mathbf{P}>0.05$. Difference not significant

$+\quad \mathbf{P}<0.05>0.01$. Difference significant

$++P<0.01>0.001$. Difference highly significant

$+++\quad P<0.001 . \quad$ Difference very highly significant 
tolerance test and the volume of duodenal contents have been graphed in Fig. 3. The numerical values of the means of the various samples will be found in Table I, with the statistical significance of the difference between the means $(a)$ of the control samples of the normal and the various abnormal groups, and $(b)$ of the sample in an abnormal group which showed the maximum increase (or reduction) after stimulation and the corresponding normal sample.

A feature of the contour of the mean responses of the whole cancer group (as in subdivisions of the group in which significant rises were evoked) has been the early rise of lipase, notably as early as 25 minutes after secretin was given. The maximal value was attained in the first post-pancreozymin sample taken at the end of an hour and was followed by a fall. The amylase, however, had not reached its peak until two hours after secretin was given. The amylase and lipase results in the cancer groups differed not only in their contour when graphed against time, but also in the extent to which they varied from the results in the normal group. With one exception the mean amylase in the control samples collected before secretin administration was similar to that of the normal group. The exception was the subgroup of non-diabetic cancer patients in whom the control amylase was significantly raised. After stimulation, again with one exception, there was a considerable rise in the amylase levels. The highest peaks reached were 180 units in the non-diabetic group and 141 units in those whose duodenal contents were normal in volume. The differences between these means and the corresponding figure for the normal group (78 units) were very highly significant. The smaller increases to 118 units in the subgroup with reduced duodenal volume and to 108 units in the whole group were nevertheless statistically significant. The exception was the diabetic subgroup in which the amylase levels were low throughout the test, the reduction in the post-secretin sample being statistically significant.

By contrast the lipase levels in the control sample were very significantly increased in the whole group and all the subgroups. The greatest increases after stimulation were to 3.65 units in the non-diabetic group and 2.6 units in the cases with normal volume of duodenal contents, but the total group and the subgroup with reduced duodenal volume also showed a marked increase to a level of 2.0 units. All these increases were very highly significant statistically, and even the considerably smaller rise to 1.1 units in the diabetic group was highly significant.

Since from the results on the control group it was known that the upper normal limits for amylase and lipase in the control samples were 134 and 1.15 units respectively, and the maximal post-stimulation values 158 and 1.5 units respectively, it was possible to determine in individual cases whether the test was positive (abnormally high) either in the control or post-stimulation samples (Fig. 2). The total number of patients with cancer of the pancreas in whom the secretin pancreozymin evocative test was positive is given in Table II, together with the

TABLE II

NUMBER OF PATIENTS WITH SIGNIFICANT VALUES

\begin{tabular}{|c|c|c|c|c|c|c|c|c|}
\hline \multirow[b]{2}{*}{ Group } & \multicolumn{3}{|c|}{ Serum Amylase } & \multicolumn{3}{|c|}{ Serum Lipase } & \multirow{2}{*}{$\begin{array}{l}\text { No. of } \\
\text { Positive } \\
\text { Evocative } \\
\text { Tests }\end{array}$} & \multirow{2}{*}{$\begin{array}{l}\text { Total No. } \\
\text { of Patients }\end{array}$} \\
\hline & Control & $\begin{array}{c}\text { Post- } \\
\text { stimulation }\end{array}$ & $24 \mathrm{hr}$. & Control & $\begin{array}{c}\text { Post- } \\
\text { stimulation }\end{array}$ & $24 \mathrm{hr}$. & & \\
\hline $\begin{array}{c}\text { Cancer of Pancreas } \\
\text { Total group } \\
\text { Impaired G.T.T. } \\
\text { Normal G.T.T. } \\
\text { Low vol. D.J. } \\
\text { Normal vol. D.J. }\end{array}$ & $\begin{array}{l}4 \\
1 \\
2 \\
3 \\
0\end{array}$ & $\begin{array}{l}9 \\
1 \\
7 \\
4 \\
3 \\
\end{array}$ & $\begin{array}{l}\mathbf{4} \\
\mathbf{1} \\
\mathbf{3} \\
\mathbf{3} \\
\mathbf{0}\end{array}$ & $\begin{array}{r}10 \\
4 \\
4 \\
3 \\
3 \\
\end{array}$ & $\begin{array}{r}15 \\
5 \\
9 \\
3 \\
4 \\
\end{array}$ & $\begin{array}{r}12 \\
4 \\
6 \\
5 \\
4 \\
\end{array}$ & $\begin{array}{r}16 \\
5 \\
9 \\
5 \\
4 \\
\end{array}$ & $\begin{array}{r}33 \\
20 \\
11 \\
10 \\
7\end{array}$ \\
\hline $\begin{array}{l}\text { Chronic Pancreatitis } \\
\text { Total group } \\
\text { Impaired G.T.T. } \\
\text { Normal G.T.T. } \\
\text { Low vol. D.j. } \\
\text { Normal vol. D.J. }\end{array}$ & $\begin{array}{l}2 \\
0 \\
2 \\
0 \\
0\end{array}$ & $\begin{array}{l}7 \\
1 \\
6 \\
1 \\
1\end{array}$ & $\begin{array}{l}5 \\
1 \\
4 \\
1 \\
1\end{array}$ & $\begin{array}{l}4 \\
1 \\
3 \\
1 \\
1\end{array}$ & $\begin{array}{r}11 \\
2 \\
9 \\
1 \\
4\end{array}$ & $\begin{array}{l}8 \\
1 \\
7 \\
1 \\
3\end{array}$ & $\begin{array}{r}11 \\
2 \\
9 \\
1 \\
4\end{array}$ & $\begin{array}{r}24 \\
13 \\
11 \\
7 \\
7\end{array}$ \\
\hline $\begin{array}{l}\text { Post-acute Pancreatitis } \\
\text { Within } 10 \text { days } \\
\text { Later }\end{array}$ & $\begin{array}{l}4 \\
0\end{array}$ & $\begin{array}{l}4 \\
0\end{array}$ & $\begin{array}{l}4 \\
0\end{array}$ & $\begin{array}{l}4 \\
3\end{array}$ & $\begin{array}{l}3 \\
5\end{array}$ & $\begin{array}{l}3 \\
5\end{array}$ & $\begin{array}{l}4 \\
5\end{array}$ & $\begin{array}{r}5 \\
15\end{array}$ \\
\hline $\begin{array}{l}\text { Biliary Tract Disease } \\
\text { Gall-bladder disease } \\
\text { Bile duct lesions } \\
\text { Post-cholecystectomy } \\
\text { Biliary cancer }\end{array}$ & $\begin{array}{l}\mathbf{3} \\
\mathbf{0} \\
\mathbf{0} \\
\mathbf{0}\end{array}$ & $\begin{array}{l}6 \\
2 \\
2 \\
1 \\
\end{array}$ & $\begin{array}{l}2 \\
0 \\
2 \\
0\end{array}$ & $\begin{array}{l}2 \\
2 \\
1 \\
1\end{array}$ & $\begin{array}{l}8 \\
6 \\
2 \\
6\end{array}$ & $\begin{array}{l}\mathbf{0} \\
\mathbf{2} \\
\mathbf{0} \\
\mathbf{0}\end{array}$ & $\begin{array}{l}9 \\
6 \\
3 \\
6\end{array}$ & $\begin{array}{l}22 \\
10 \\
13 \\
11\end{array}$ \\
\hline Liver Disease & 1 & 2 & 0 & 1 & 3 & 1 & 3 & 13 \\
\hline
\end{tabular}


analysis for diabetic and non-diabetic patients. Of the 20 patients with impaired glucose tolerance the control amylase was significantly elevated in one and the lipase in four; after stimulation the maximal lipase was raised in five. If the results for both enzymes in the diabetic group are combined, the evocative test gave a significant rise in five of the 20 patients whereas the control value was significantly raised in four. On the other hand, in the 11 nondiabetic patients control values for amylase exceeded normal in two and for lipase in four instances. Following stimulation the maximal amylase was significantly raised in seven and lipase in nine of the 11 patients. If the results for both enzymes are combined a raised value was found in six patients before and in nine after stimulation. In one of the two negative tests the primary lesion may have originated in the common bile duct. In both diabetic and non-diabetic patients serum lipase seemed to be a more sensitive index of pancreatic disease than serum amylase. The glucose tolerance could not be measured in two patients. One of these showed a significant rise in amylase (serum lipase was not estimated) and in the other high amylase and lipase values obtained in the control specimen were maintained throughout the test.

The postprandial serum amylase taken at 24 hours was high in the same four individuals as the fasting control serum amylase. The 24-hour serum lipase was raised in 12 patients, in seven of whom the fasting control lipase was raised. In all but two post-stimulation values had been significantly increased. In three of the patients with elevated fasting lipases the 24-hour value was normal and two of these showed little rise on stimulation with secretin and pancreozymin.

Between individual responses there were wide differences which were unrelated to the duration of symptoms. This lack of correlation was to be expected in view of the variation in invasiveness and in the site of the cancer. Nevertheless in the three cases of ampullary cancer studied within the first month of jaundice (a time during which cancer of the ampulla might be expected to produce duct obstruction rather than acinar destruction), a prompt and decided elevation of both amylase and lipase was obtained in the two cases studied only a fortnight after the onset of jaundice, but in the third studied at one month a significant rise in lipase only was evoked. In a fourth patient with ampullary cancer studied six months after the appearance of jaundice no rise in either amylase or lipase could be detected. Three patients in whom the cancer had been removed by subtotal pancreatectomy showed low initial values which changed but little after stimulation with secretin and pancreozymin.
(2) Pancreatitis.-Forty-four patients had suffered from pancreatitis. Two main divisions of the group are analysed, one "post-acute pancreatitis" (20 cases) and the other chronic pancreatitis ( 24 cases). In "post-acute pancreatitis" are included those patients who had suffered previously from acute attacks of pancreatitis but who showed no evidence of permanent pancreatic damage such as continuing diabetes, steatorrhoea, or calcification of the pancreas. The chronic pancreatitis group included those presenting with a long history of repeated attacks and showing evidence of permanent glandular damage such as diabetes, steatorrhoea, or calcification, and those in whom the surgeon noted unequivocal hardening of the pancreas sufficient to justify without doubt such a diagnosis.

One patient in the chronic pancreatitis group, in whom a gross elevation of the serum enzymes occurred after stimulation, is considered separately. Of the remaining 23 patients the glucose tolerance was impaired in 13 . In 14 patients the duodenal contents obtained in response to secretin and pancreozymin were aspirated, and in seven of these the volume of the contents was low (less than $150 \mathrm{ml}$. in 60 minutes). The glucose tolerance was impaired in five of seven of these patients, but in only two of the seven in whom the volume was normal.

In the chronic pancreatitis group the results are of a pattern remarkably similar to that of cancer of the pancreas. The mean responses for the total group and the groups subdivided according to the glucose tolerance test and volume of duodenal contents are graphed in Fig. 4. The numerical values and statistical results are given in Table $I$. The amylase control level was significantly increased only in the group with normal glucose tolerance. After stimulation the increase in this group, to 157 units, was very highly significant. The peak response, 116 units, in the group in which the volume of duodenal contents was normal, was also significant, but neither the smaller increases in the total group and in those with impaired glucose tolerance nor the slight decrease in the patients with reduced volume of duodenal contents differed significantly from the corresponding mean results in normal subjects.

The lipase results were in general similar, except for a greater elevation above the normal means. The control levels of the groups with normal duodenal volumes and normal glucose tolerance were significantly increased, very highly so in the latter case. After stimulation not only did these groups reach very highly significant maxima of 2.3 units and 3.7 units respectively, but the lipase in the total group, in which the amylase was not 

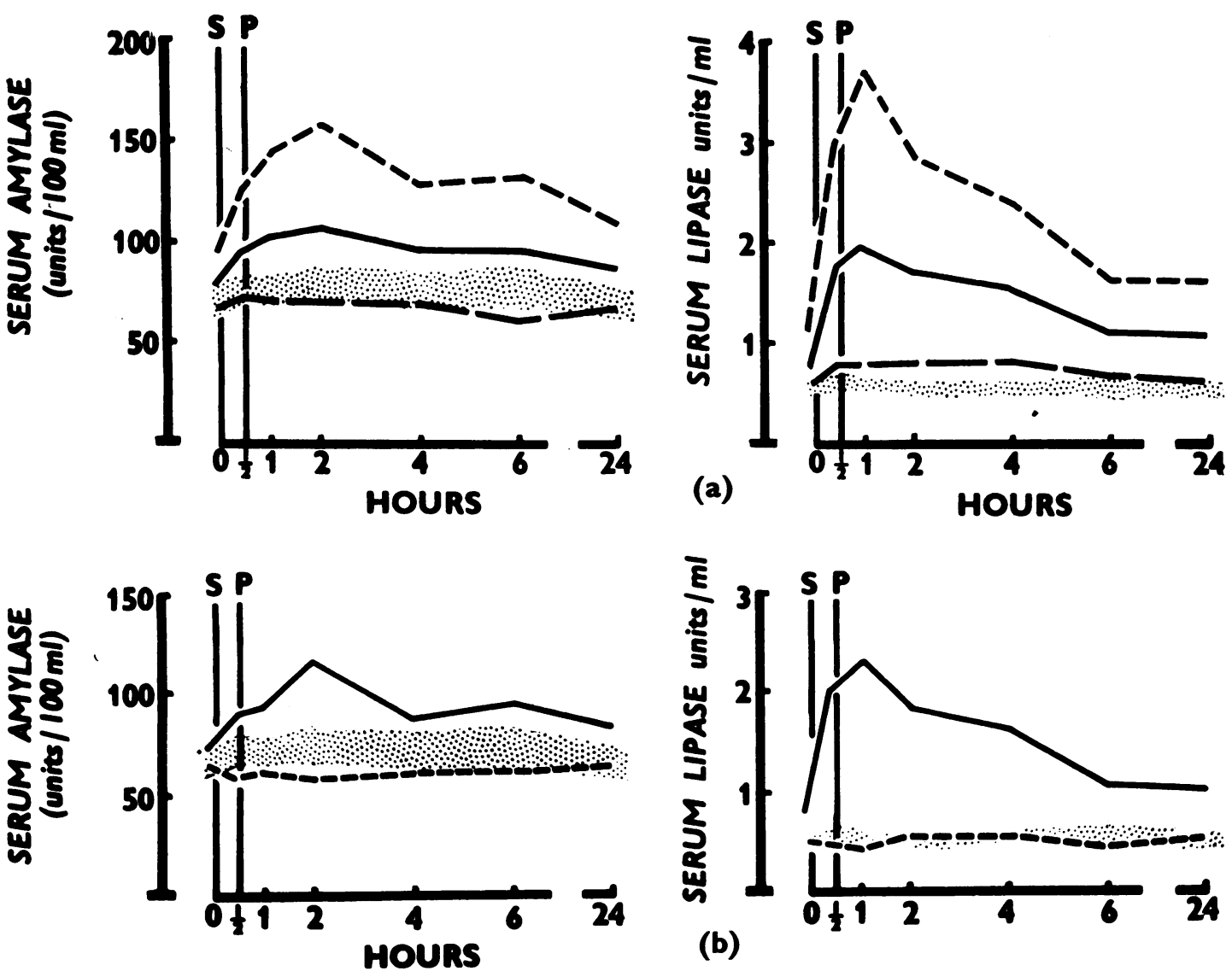

FIG. 4.-The Evocative Test.-Mean serum amylase and lipase evoked by secretin and pancreozymin in chronic pancreatitis.

(a) Whole group with diabetic and non-diabetic subgroups.

Whole group (23) _- - - - - - Non-diabetic (10) Diabetic (13)

(b) Subgroups with normal and reduced volume of duodenal contents. Normal volume (7) _ - - - - - - Reduced volume (7)

appreciably raised, was significantly increased to 1.7 units. In the more advanced cases, the groups with impaired glucose tolerance and reduced volume of duodenal contents, there was no significant difference from the normal group. In all the groups in which increases occurred in the mean serum enzyme, lipase attained its maximum earlier than the amylase.

As in the cancer cases, serum lipase seemed to be a more sensitive index than serum amylase in individual cases. A positive evocative test was more frequently obtained in the non-diabetic group than in the diabetic group (Table II). In none of the 13 patients with impaired glucose tolerance was the control serum amylase elevated; the control lipase was elevated in one. After stimulation the maximal amylase was significantly raised in one patient and the lipase in two. In the group of 10 patients with normal glucose tolerance the control amylase was raised in two and the lipase in two instances. Following stimulation a significantly increased value for amylase was attained in five cases and for lipase in eight. If the results for both enzymes are combined the evocative tests gave a significant rise in two of the 13 patients in the diabetic group whereas the control value was significant in one. In the non-diabetic group of 10 a significant rise was obtained in eight patients compared with a significant control value in three.

The postprandial serum amylase taken at 24 hours was high in four patients, in one of whom the fasting control value was raised; the postprandial serum 
lipase was raised in seven patients, in three of whom the fasting control value was raised. In all seven well marked post-stimulation increases were obtained.

One patient with chronic relapsing pancreatitis and multiple stones in the pancreatic duct has been omitted from the analysis: in this instance the amylase rose from 80 to 379 units in six hours to reach 765 units at 24 hours and the lipase from $2 \cdot 3$ to 42 units at six hours, and fell to 21 units at 24 hours. Paradoxically the output of duodenal contents in 60 minutes was low $(44 \mathrm{ml}$. in $60 \mathrm{~min}$., $0.95 \mathrm{ml}$. per kilogram of body weight) though the glucose tolerance test was normal in this patient.

In the whole "post-acute pancreatitis group" the mean control serum amylase was not appreciably different from normal, but there was a highly significant maximal increase (to 105 units) after stimulation. The increase in both the control ( 1.0 units) and the maximal (1.3 units) lipase figures was very highly significant (Table I).

Five patients were examined within 10 days of an acute attack. One man was unwittingly stimulated during a mild attack of acute pancreatitis when the control serum amylase was 1,270 units and the control lipase 12.5 units. The maximal poststimulation value for amylase rose to 2,010 units and lipase to 14.5 units. (This result is excluded from the calculation of mean values for the group.) In three of the other four patients examined within 10 days of the acute attack the control amylase was elevated, and the lipase in two of these three and one other. In all four one or other control value was abnormal. The post-stimulation serum amylase was significantly elevated in the same three patients as the control amylase and the post-stimulation lipase in two of the three in whom the control lipase was raised. A feature characteristic of the response of the immediate post-pancreatitis phase was that the post-stimulation values did not exceed the control values greatly; rather than a peak of response a plateau pattern was present.

Neither the control nor post-stimulation serum amylase was abnormal in any of the 15 patients examined after the tenth day following an attack, but the fasting serum lipase was abnormal in three of these patients and the post-stimulation serum lipase was elevated in these three and two others, five in all. The evocative test was positive in all three patients in whom the glucose tolerance test was impaired. The volume of the duodenal contents was not significantly reduced in any members of the group. In the whole group gall stones were present in four of the eight patients in whom the evocative tests were positive and in three of the 11 in whom they were negative.
Biliary Tract and Liver Disease.-A group of 69 patients with biliary tract and liver disease has been studied. It includes 45 patients with nonmalignant disease of the gall bladder or bile ducts, 11 patients in whom cancer appeared to arise primarily in the gall bladder or bile ducts, and 13 patients with liver disease, two with' acute hepatitis and 11 with cirrhosis of the liver.

(1) Non-malignant Group.-In 22 patients gall bladder disease with or without gall stones was present (gall bladder subgroup); 10 had lesions, either stone or simple stricture of the extrahepatic bile ducts (duct lesions subgroup); and in 13 the gall bladder had been surgically removed before the test (post-cholecystectomy subgroup). In all but three of this last subgroup lesions affecting the extrahepatic bile ducts were found at operation.

A number of diabetic patients known to have biliary disease was deliberately included in this study. A few patients included in this non-malignant group may possibly have suffered from pancreatitis, but unless there was either convincing evidence of this or the surgeon was able, at the time of operation, to demonstrate pancreatitis unequivocally the patient has been allocated to this group on account of the proved lesion of the biliary tract. Glucose tolerance was impaired in 11 of the 45 patients with simple biliary disease. The 11 cases were distributed as follows: seven in the gall bladder subgroup, three associated with lesions of the bile ducts, and one following cholecystectomy. The volume of duodenal contents aspirated in response to secretin and pancreozymin was not reduced in simple biliary tract disease.

The mean results in the three subgroups are shown graphically in Fig. 5. The numerical values and statistical evaluation are in Table I. The control lipase was significantly increased in the cases with duct lesions. Apart from this none of the prestimulation amylase or lipase values deviated significantly from normal. After stimulation, however, significant increases in amylase and lipase occurred in all three subgroups, the absolute increases and their statistical significance being greatest in the patients with duct lesions. Again in these groups the maximal elevation in lipase took place earlier than the maximal increase in amylase.

When the individual cases were considered (Table II), it was found that in the gall bladder subgroup the control amylase was elevated in three and the control lipase in two patients. A significant response for amylase was evoked after stimulation in six patients, and for lipase in eight, a combined response in nine of the 22 patients. At 24 hours the amylase remained elevated in two patients but the lipase was normal in all the cases in 

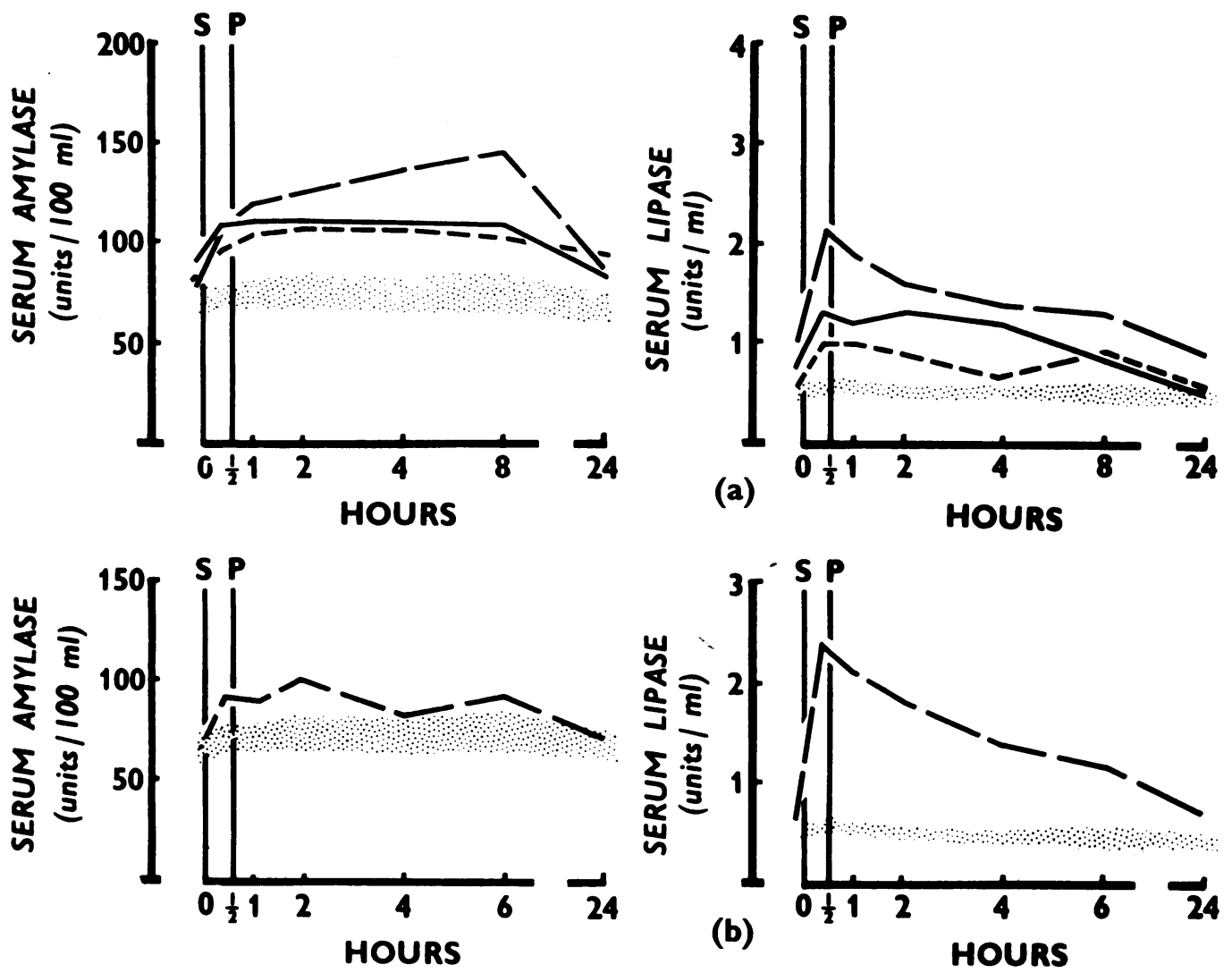

FIG. 5.-The Evocative Test.-Mean serum amylase and lipase evoked by secretin and pancreozymin in biliary lesions.

(a) Non-malignant disease
(a) of gall bladder
(c) post-cholecystectomy - - - -
(22)
b) Cancer of biliary tract (11).

(b) of common bile duct (10)

which it was estimated. Three of the positive evocative tests were obtained in diabetic patients, in one of whom the rise of amylase from 103 to 200 units per $100 \mathrm{ml}$. and lipase from 0.8 to 5.8 units per ml. was striking. In the subgroup with duct lesions the control amylase was not elevated in any instance but the control lipase was abnormally high in two patients. After stimulation the maximal amylase became significant in two and the maximal lipase in six patients, a total of six of the 10 patients of the subgroup giving positive evocative tests. The 24-hour amylase was not elevated in any instance, but the 24-hour lipase remained elevated in the two patients with high control values. The test was positive in two of the three diabetic patients in this subgroup. In the post-cholecystectomy subgroup the control serum amylase was not raised in any individual, and the control serum lipase was high in one patient. After stimulation the serum amylase became significantly high in two patients and remained high in both at 24 hours. The serum lipase became high in two patients but had fallen at 24 hours. Of the 13 members of the subgroup the evocative test was positive in three, none of whom had an impaired glucose tolerance test.

(2) Cancer of Gall Bladder or Bile Ducts.Primary cancer of the gall bladder was present in two and of the bile ducts in nine patients. The liver was grossly infiltrated with secondary deposits in two instances. Details of the mean results will be found in Fig. 5 and Table I. Before stimulation neither amylase nor lipase was increased. Two hours after secretin the mean amylase had increased significantly to 100 units. The lipase reached a very highly significant peak of 2.4 units in the sample collected 30 minutes after secretin. Examination 
of the results in individual cases revealed that the control serum amylase was normal in all, but the control serum lipase was slightly raised ( 1.3 units) in one patient. After stimulation a significant response for amylase was obtained in one patient and for lipase in six patients including the one in whom the raised amylase had been found (Table II). The serum lipase attained its maximum 25 minutes after secretin in five of these tests, and one hour after secretin in the remaining positive test. The raised values for both amylase and lipase had all returned to normal in $\mathbf{2 4}$ hours. Neither of the two diabetic patients with biliary cancer had positive evocative tests. Gall stones were found at operation in four patients of the group, two of whom had positive evocative tests.

(3) Liver Disease.-Since serum lipase is sometimes elevated in cirrhosis of the liver, the test was performed on 13 patients, two with acute hepatitis and 11 with cirrhosis, none of whom had gall stones. There was no significant deviation from normal in the mean amylase results before or after stimulation in this group. In contrast the mean lipase was significantly raised before and very highly so after stimulation. Among the individual results one patient had a control serum amylase of 150 units which after stimulation rose 308 units. A positive amylase response was obtained in a second patient, but in neither was the 24-hour value raised. The control serum lipase was only slightly raised $(1 \cdot 2$ units per ml.) in one of the group, but a rise was evoked in this patient and two other cirrhotic patients. The 24-hour value remained high (2.3 units per ml.) in the patient with the raised fasting control value. Of the 13 patients with liver disease a positive evocative test was present in three, all of whom had cirrhosis of the liver. Only one of four patients with abnormal oral glucose tolerance gave a positive evocative test.

JuXTAPANCREatic Disease.-Disease arising in organs and structures adjacent to the pancreas, other than in the biliary tract may involve the pancreas. Direct extension or pressure from such lesions was considered to be responsible for six positive evocative tests, in two cases of duodenal ulcer adherent to the pancreas, in two patients with cancer of the pylorus infiltrating the pancreas, and in two others in whom the cancer arose at a distance, in the bronchus and rectum respectively, but in whom the para-aortic lymph nodes of the posterior abdominal wall were grossly infiltrated. None of these patients was diabetic.

Miscellaneous Group.-A group was formed to include certain patients in whom the diagnosis remained in doubt. Negative evocative tests were obtained in two patients who had been suspected of having had acute pancreatitis, in a third patient whose abdominal pain resembled gall bladder or pancreatic pain, and in two diabetic patients the source of whose abdominal pain could not be traced.

It is convenient to include two other patients in this group who do not fall naturally into the classified groups, and both of whom gave positive evocative tests. A woman aged 67 years had received deep radiation therapy for a malignant ovarian tumour in 1952. In 1957 she developed acute upper abdominal pain followed by steatorrhoea, and a diagnosis of pancreatitis was made on clinical grounds. The serum amylase rose from a fasting value of 126 units to 177 units after stimulation and the serum lipase from 0.4 to 3.0 units. A man aged 58 had regional ileo-colitis densely adherent to the bladder and leading to chronic pyelonephritis and finally uraemia. The serum amylase rose from 115 to a maximum of 174 units per $100 \mathrm{ml}$., and the serum lipase from 1.5 to 2.4 units per $\mathrm{ml}$. At necropsy three weeks later the pancreas was normal.

\section{Discussion}

In 1954, Dreiling and Richman, summarizing the literature on evocative tests of pancreatic function to that time, comment that "the extensive investigations by many groups into serum pancreatic enzyme response to various secretagogues have produced such disparate findings and conclusions as to result in considerable confusion". Part of this confusion has been due to the failure of some workers to distinguish the two different conceptions underlying on the one hand the evocative-obstructive tests in which morphine is used in addition to pancreatic stimulants, and on the other the simple evocative tests in which no such agent is given to obstruct the pancreatic outflow.

The simple evocative test used in this study is based on the observation that an adequate but submaximal stimulation of the exocrine secretion of the pancreas will not lead to a rise in the pancreatic enzymes in blood serum when the gland is normal, but in the diseased gland, should the outflow of pancreatic juice be impeded, enzymes are absorbed into the blood stream after such stimulation and a significant rise in the amount of circulating pancreatic enzyme can be measured. This increase can of course occur only if the gland contains sufficient functioning acinar tissue to produce the enzymes.

So many different pancreatic stimulants have been used in such varied dosage in evocative tests that it 
is not surprising that a consistent pattern of response has not emerged. Various parasympathomimetic drugs-mecholyl, carbachol, urecholine, and neostigmine-have been given to simulate vagal stimulation. But precise data on the influence of the abdominal vagus on the pancreas of man are not available and the effect of these drugs on the pancreas when used alone is unreliable (Thomas, 1950). The results are not necessarily reproducible since if the gastric contents are not removed a variable amount of gastric acid may pass into the duodenum to stimulate the pancreas secondarily through the physiological secretin and pancreozymin mechanisms. Secretin has also been used, some preparations of which have been free of enzyme stimulant, but others may have contained variable amounts of pancreozymin. Vagal stimulants have been given in conjunction with secretin to raise the concentration of enzymes in the pancreatic secretion.

Our investigations of the physiological activity of pancreozymin in man, planned to compare its action on duodenal contents with that of secretin, have provided a means of stimulating specifically the enzyme output of the pancreas. Secretin used in the dose of 1.7 units per kilogram of body weight and followed in half an hour by 1.7 units of pancreozymin has given results which in normal subjects fulfil the primary criterion of a simple evocative test of the pancreas, that in the normal pancreas a minimal and insignificant rise in serum enzyme values occurs. Unfortunately it is not possible to compare the results of our experiments with the effects of secretin alone on the serum enzymes, since this effect of secretin may not have been completed by the time pancreozymin is given $\mathbf{3 0}$ minutes later, and it was not considered justifiable to submit outpatients to a further test and series of venepunctures to decide this point. From the available data, however, it can be stated that in an appreciable number of the positive tests in abnormal subjects a prompt increase in enzyme, notably lipase, is present within 25 minutes of giving secretin in the blood specimen taken immediately before the pancreozymin is injected.

Before the investigation had been long in progress it was appreciated that the method of Goldstein and Roe we had adopted to measure serum lipase, though adequate for estimating lipolytic activity in duodenal contents, did not in fact measure the changes in serum lipase in response to pancreatic disease in man. Thereafter we used a modification of the method of Cherry and Crandall with olive oil as substrate, which gave good results in the hands of Lopusniak and Bockus (1950). Statistical comparison of the mean serum lipase obtained by this method with the mean serum amylase has proved that lipase in serum is a more sensitive index of pancreatic disease in both fasting control specimens and in evocative tests, a point not appreciated by workers who have used serum amylase alone to measure the effects of stimulation. From a scrutiny of our results this does not seem to depend on the amount of bilirubin in the blood serum at the time of the test. It has, however, been found necessary to exclude serum lipase results obtained from lysed sera, which gave abnormally low readings.

We have, as far as possible, carried out an oral glucose tolerance test in the patients suffering from pancreatic disease, following the observation that in cancer of the pancreas progressive deterioration of endocrine function was not infrequent. It soon became apparent that the evocative test was less likely to be positive when glucose tolerance was impaired than when glucose tolerance was normal. It appears, therefore, that when glucose tolerance is impaired to a considerable extent due to pancreatic disease appreciable destruction of acinar function has also taken place. The fasting serum enzyme also is less likely to be elevated when glucose tolerance is impaired. Lopusniak and Bockus (1950), using secretin alone, have already noted the converse of this statement, that a greater elevation of serum amylase and lipase was evoked in those patients with pancreatic disease in whom the resting serum enzymes were raised. A comparison has been made between the significance of the mean control and mean maximal post-stimulation values. It is important to note that value of " $t$ " is always very much greater for the peak mean than the control mean in those groups where this value is significant. This underlines the value of stimulation as practised in this simple evocative test. In many cases duodenal intubation has been performed, and a correlation of the evocative test and duodenal volume in chronic pancreatitis and cancer of the pancreas indicates that a positive evocative test is seen more frequently when the duodenal output is adequate than when it is diminished. There is a striking difference between the mean results of the inflammatory and the malignant cases with low duodenal volume, the enzyme levels being much higher in the malignant cases (Figs. 3 and 4). This suggests that in carcinoma of the pancreas a low duodenal volume is less clearly indicative of extensive acinar damage, which presumably develops relatively slowly after early obstruction of the duct in these cases. A positive correlation in chronic pancreatic disease, both cancer and pancreatitis, also exists between the diabetic state and a low volume of duodenal contents in response to stimulation of the pancreas. 
Patients who have had acute pancreatitis and recovered may show no functional derangement of the gland. It seems worthy of note, however, that those patients stimulated within 10 days of an acute attack of mild or moderate severity and still showing an elevated fasting amylase or lipase in serum have responded in a characteristic manner, the level continuing at about control level throughout the test, and remaining at this raised level at 24 hours. This pattern of response may be related to the increased acinar-capillary permeability shortly after an acute attack of pancreatitis (Sun and Shay, 1957). Apart from those cases only a few tests in this group have been positive. Of these permanent damage may have been present in the pancreas in one or two which more correctly might find a place in the chronic pancreatitis group. In some others coexisting disease of the biliary tract may have been a factor in producing the positive evocative test.

The group with biliary tract disease includes a considerable number of diabetic patients, but in this instance there was no reason to attribute the impaired glucose tolerance to pancreatic disease. In contrast to the findings in chronic pancreatic disease, in biliary and liver disease the proportion of positive evocative tests in non-diabetic patients is the same as the proportion in diabetic patients.

The evocative tests are more frequently positive in association with stone and stricture of the bile ducts when the gall bladder is present than when it has been removed, an indication that in addition to the mechanical factors of stone or stricture of the bile ducts impeding pancreatic flow, contraction of the sphincter may play a part, since the sphincteric mechanism is destroyed by cholecystectomy. Positive evocative tests have been obtained even with no evidence of stone in the common bile duct. A few of these may be instances of mild pancreatitis, but stones in the neck of the gall bladder or impacted in the cystic duct were thought to be particularly liable to cause a rise in serum enzymes. The close association of gall bladder and pancreatic disease is again emphasized by these results.

A surprising feature has been the number of positive evocative tests obtained in cancer sited primarily in the bile ducts. That early ampullary cancer should give a marked response is not unexpected. In a few instances the primary site may have been thought to be in the lower common duct whereas in fact the tumour was pancreatic or the pancreatic duct may have been involved in the tumour at an early stage; in three patients with positive tests gall stones were present in addition to cancer. The positive tests were not associated with secondary deposits in the liver visible to the naked eye, nor was the amount of bile in the serum thought to be a factor in determining the higher number of positive lipase tests compared with amylase tests (a ratio of 6 to 1) for reasons already stated. Duodenal intubation was done on three patients with biliary cancer, none of whom gave a positive evocative test, and an adequate volume was obtained from all three. The fact remains that the evocative test alone cannot be used to distinguish bile duct cancer from primary cancer of the pancreas.

In the two instances when the pancreas was involved secondarily by cancer of the stomach positive tests were obtained. Positive evocative tests were also encountered in a patient with cancer of the bronchus and another patient with cancer of the rectum. These results were accounted for by growth involving the para-aortic glands in close relation to the pancreas. Raised serum lipase values have been reported in advanced metastatic cancer of the liver, when the primary tumour was in the bronchus (Edmondson, Berne, Homann, and Wertman, 1952) and in the colon (Johnson and Bockus, 1940). Neither of our patients had detectable secondary deposits in the liver at the time of the test.

Johnson and Bockus (1940) and Cummins and Bockus (1951) report raised serum lipase values in liver damage even when there is no pancreatitis. We have found positive evocative tests in three of 11 patients with cirrhosis of the liver, in two of whom both amylase and lipase were abnormal, in the third lipase only. Cummins and Bockus have suggested three possible mechanisms to account for the elevation of these enzymes in the serum of cirrhotics: that the enzymes are released from damaged hepatic cells, that an enzyme destroying mechanism present in normal liver fails, and that mild pancreatitis coexists. High enzymes in serum may also be additional evidence of the development of anastomoses between the portal and systemic circulations.

We have encountered raised amylase and lipase values after stimulation in a patient with ileal ulceration, steatorrhoea, and advanced renal failure due to chronic pyelonephritis. Dankner and Heifetz (1951) report increased serum enzymes in renal failure with nitrogen retention, though Gross and Comfort (1956) have found normal values in this condition. In a study of 50 patients with uraemia we have encountered raised values for serum amylase and lipase in nine of the 14 patients in whom the blood urea exceeded $375 \mathrm{mg}$. per $100 \mathrm{ml}$. (Burton, Eddleston, Howat, and Wilson, 1959). This, essentially a terminal event, was not a factor responsible for the raised enzymes in any other patient in this series.

Knight et al. (1949), who did serial estimations of serum amylase at 30-minute intervals over two 
hours following the injection of $1 \mathrm{mg}$. of prostigmin methyl sulphate intramuscularly, have analysed the curve of response in an attempt to draw conclusions about the degree of obstruction and pancreatic secretory capacity. This does not always seem possible from information gleaned solely from the evocative test, although early obstructive pancreatic lesions such as ampullary cancer may give normal resting values and a considerable rise following stimulation. Should no rise occur or even a fall result, the interpretation of an essentially functional test in anatomical terms becomes more speculative. It seems more rewarding to obtain evidence of diminished pancreatic function from a collection of duodenal contents as proposed by Sun and Shay (1957). Our results suggest that evocative tests provide earlier information of pancreatic derangement than does examination of the duodenal contents which are progressively diminished in enzyme output, bicarbonate, and finally volume as pancreatic disease progresses. From the data of this study it has been possible, by using a simple oral glucose tolerance test, to establish a direct relationship between impaired glucose tolerance and diminished volume of pancreatic secretion and an inverse relationship with positive evocative function tests. Estimation of glucose tolerance and evocative tests in which secretin and pancreozymin are used as pancreatic stimulants show some overlap (Burton, Hammond, Harper, Howat, Oleesky, and Varley, 1956), and together indicate chronic pancreatic disease in a considerable proportion of patients. In the combined groups of cancer of the pancreas and chronic pancreatitis of this present series, an indication of the presence of pancreatic disease has been obtained in all but four of 57 patients, using the evocative test in conjunction with the oral glucose tolerance test.

False positive evocative tests do occur in relation to biliary tract disease, occasionally in cancer not involving the pancreas, in cirrhosis of the liver, and in the terminal stages of uraemia. Such exceptions serve as a reminder that function tests should be interpreted only in terms of function and that before anatomical or pathological interpretations are made, a careful correlation with other clinical and biochemical data is necessary. The association of positive evocative tests with biliary disease, and especially with lesions of the common bile duct, re-emphasizes the close functional, developmental, and anatomical relationship between the bile ducts and pancreatic ducts, and the frequent association of biliary and pancreatic disease.

We are grateful to Miss Josephine Smith who undertook some of the chemical determinations for this study.

\section{REFERENCES}

Burton, P., Eddleston, B., Howat, H. T., and Wilson, J. A. C. (1959). Serum amylase and serum lipase in uraemic states. Unpublished.

-, Evans, D. G., Harper, A. A. Howat, H. T. Scott, J. S., Oleesky, S., and Varley, H.' (1960). A test of pancreatic function in man, based on the analysis of duodenal contents after administration of secretin and pancreozymin. Gut, 1. 111 . Hammond, E. M., Harper, A. A., Howat, H. T., Oleesky, S., and Varley, $H$. (1956). The use of secretin and pancreozymin with glucose tolerance tests in the diagnosis of pancreatic with glucose tolerance tests in the diagnosis
disease. Gastroenterologia (Basel) 86,463 .

Cherry, I. S., and Crandall, L. A. (1932). The specificity of pancreatic lipase: its appearance in the blood after pancreatic injury. Amer. J. Physiol., 100, 266.

Crick, Joan, Harper, A. A., and Raper, H. S. (1949). On the preparation of secretin and pancreozymin. J. Physiol. (Lond.), $110,367$.

Cummins, A. J., and Bockus, H. L. (1951). Abnormal serum pancreatic enzyme values in liver disease. Gastroenterology, $18,518$.

Dankner, A., and Heifetz, C. J. (1951). The interrelationship of blood and urine diastase during transient acute pancreatitis. Ibid., 18, 207.

Dreiling, D. A., and Richman, A. (1954). Evaluation of provocative blood enzyme tests employed in the diagnosis of pancreatic disease. A.M.A. Arch. intern. Med., 94, 197.

Edmondson, H. A. Berne, C. J., Homann, R. E., and Wertman, Maxine (1952). Calcium, potassium, magnesium and amylase disturbances in acute pancreatitis. Amer. J. Med., 12, 34

Fisher, R. A. (1934). Statistical Methods for Research Workers, 5th ed., p. 120. Oliver \& Boyd, Edinburgh.

Geigy, J. R.'(1956). Documenta Geigy Scientific Tables, 5th ed. p. 31: Statistical Methods in Medicine. Geigy Pharmaceutical Co., Basel.

Goldstein, N. P., Epstein, J. H., and Roe, J. H. (1948). Studies of pancreatic function. IV. A simplified method for the determination of serum lipase, using aqueous tributyrin as substrate, with one hundred normal values by this method. J. Lab. clin. Med., 33, 1047.

- and Roe, J. H. (1943). Studies of pancreatic function. I. The determination of the lipidolytic enzymes of blood serum. Ibid., 28, 1368 .

Gross, J. B., and Comfort, M. W. (1956). Chronic Pancreatitis. Amer. J. Med., 21, 596.

Henry, R. J., Sobel, C., and Berkman, S. (1957). On the determination of "pancreatitis lipase in serum." Clin. chem., 3, 77.

Johnson, T. A., and Bockus, H. L. (1940). Diagnostic significance of determinations of serum lipase. Arch. intern. Med., 66, 62.

Knight, W. A., Muether, R. O., and Sommer, Anne J. (1949). Chronic recurrent pancreatitis. II. Serial serum diastase levels following prostigmine stimulation. Gastroenterology, 12,24 .

Lopusniak, M. S., and Bockus, H. L. (1950). Study of pancreatic serum enzymes following secretin injection in pancreatic affections. Ibid., 16, 294.

Myhre, J., Nesbitt, S., and Hurly, J. T. (1949). Response of serum amylase and lipase to pancreatic stimulation as a test of pancreatic function. Ibid., 13, 127.

Popper, H. L., and Necheles, H.'(1943). A new test for pancreatic function: experimental observations. Ibid., 1, 490.

- Olson, W. H., and Necheles, H. (1943). A new test for pancreatic function, II. Experimental observations. Surg. Gynec. Obstet., 77, 471.

Somogyi, M. (1938). Micromethods for the estimation of diastase. J. biol. Chem., 125, 399.

Sun, D. C. H., and Shay, H. (1957). Value of combined study of serum enzymes and duodenal contents after secretin in the diagnosis of diseases of the pancreas. Gastroenterology, 32, 212 .

Thomas, J. E. (1950). The External Secretion of the Pancreas, p. 79. E. Charles C. The External Secretion of 